\title{
Examining Student Engagement with Science Through a Bourdieusian Notion of Field
}

\author{
Spela Godec ${ }^{1}$ (D) $\cdot$ Heather King ${ }^{2} \cdot$ Louise Archer $^{1} \cdot$ Emily Dawson $^{3} \cdot$ Amy Seakins $^{4}$
}

Published online: 6 August 2018

(C) The Author(s) 2018

\begin{abstract}
Student engagement with science is a long-standing, central interest within science education research. In this article, we examine student engagement with science using a Bourdiusian lens, placing a particular emphasis on the notion of field. Over the course of one academic year, we collected data in an inner London secondary science classroom through lesson observations, interviews and discussion groups with students, and interviews with the teacher. We argue that applying Bourdieusian theory can help better understand differential patterns of student engagement by directing attention to the alignment between students' habitus and capital, and the field. Student behaviours that did not meet the requirements of the wider field were not recognised and valued as constituting engagement. Even when the 'rules of the game' of the science classroom were understood by the students, the tensions they experienced within the field made engaging with science impossible and undesirable. We discuss how a greater focus on the field can be useful for planning future interventions aimed at making science education more equitable.
\end{abstract}

\section{Introduction}

In recent years, there have been many calls and subsequent initiatives to enhance, broaden and prolong student engagement with science. Enhanced student engagement (we discuss the term in more detail in the next section) is associated with better learning, improved academic

Spela Godec

s.godec@ucl.ac.uk

1 Department of Education, Practice and Society, UCL Institute of Education, University College London, 20 Bedford Way, London WC1H 0AL, England

2 School of Education, Communication and Society, King's College London, Waterloo Bridge Wing, Franklin Wilkins Building, London SE1 9NH, England

3 UCL Department of Science and Technology Studies, University College London, 22 Gordon Street, London WC1E 6BT, England

4 Academic Partnerships, Imperial College London, South Kensington Campus, London SW7 2AZ, England 
attainment and increased long-term participation in science (Friedman and Ginsburg 2013; Maltese and Tai 2010; Osborne and Dillon 2008). There has been an extensive focus on factors 'within' students that affect their engagement, but fewer studies have sought to understand the external factors shaping differential engagement with science and the interaction between these internal and external considerations. Educational contexts play an important role in how and to what extent students engage with science: how they are supported to engage, and how they are recognised and valued for the ways they do so. Researchers (e.g. Brown 2006; Lemke 1990) have raised concerns that there tend to be particular ways of behaving and 'talking science' in science classrooms that are privileged over others. The expectations are manifested, for instance, in notions of who is perceived to be a 'good' science student and what is regarded to be 'good' engagement (Carlone 2004; Carlone et al. 2014). Our interest in applying a Bourdieusian theoretical lens arises from a social justice perspective. We consider Bourdieusian theory to provide useful 'thinking tools' for understanding student engagement as a function of the physical and social space with its inherent power relations. In this article, we address the following research question: To what extent does an explicit focus on the field offer a productive way to explain variable student engagement with science? We explore this question through qualitative data collected during science lesson observations in one Year 8 science class (12-13-year-old students) in an inner city London (UK) secondary school, along with student interviews and discussion groups, and teacher interviews.

\section{Student Engagement}

A review of the literature suggests that engagement is not a term which is consistently applied. Rather, it is open-ended and interpreted in a variety of ways. For instance, in Ainley and Ainley's (2011) work, engagement with science is a proxy for enjoyment and interest. Hampden-Thompson and Bennett (2013), meanwhile, have interpreted student engagement with science by examining students' motivation towards science, enjoyment of science and future orientation towards science. Others have aligned engagement with science with participation in science-related activities: the term engagement has been used to frame studies focused on the frequency of participation in activities (Atkinson and Mason 2014; Atkinson et al. 2014) and the intensity of such involvement (Barriault and Pearson 2010).

Fredricks et al. (2004) have offered a conceptualisation of student engagement as consisting of three forms: (i) affective-emotional engagement including attitudes, interest, sense of belonging and identification; (ii) cognitive engagement including persistence, willingness, motivation and psychological investment to learn; and (iii) behavioural engagement including participation in activities. This approach to engagement as a multidimensional concept has been adopted by many studies in education research more generally (see Christenson et al. 2012a) as well as in science education specifically (e.g. Hampden-Thompson and Bennett 2013). Recently, some scholars have proposed additional dimensions to Fredricks and her colleagues' triad, such as academic engagement (e.g. time spent on task, homework completion; see Appleton et al. 2006) and social engagement (the quality of social interactions; see M.-T. Wang et al. 2016). A further way of examining student engagement has been to distinguish between students' in-the-moment engagement ('acts of engagement') and wider aspects of their engagement, such as their identities and dispositions ('engagement dispositions'). Lawson and Lawson (2013) have described acts of engagement as 'various states of experience of individuals as they participate in discrete activities at particular moments in 
time' (Lawson and Lawson 2013, p. 442, original emphasis). This would include what engagement might be observed (and later reflected upon) during a lesson.

The student engagement literature has also sought to characterise various levels of student engagement, asking questions about the extent to which students are engaged with a particular subject or domain, or not. Substantive or action-oriented forms of engagement have been discussed in terms of 'deep' (Crick 2012) and 'agentic' engagement (Reeve 2012; Reeve and Tseng 2011). These involve prolonged, purposeful, authentic and action-oriented behaviours, and positive affect such as interest and positive attitudes. Such strong forms of student engagement are the goal of many educators. On the other hand, 'procedural' (Pekrun and Linnenbrink-Garcia 2012) and 'compliant' (Crick 2012) student engagement is the kind that appears passive and needs to be stimulated externally. In reviewing different levels of engagement, it is important to also consider acts of disengagement (Skinner et al. 2008; Skinner et al. 2009). Disengagement is not simply the absence of engagement, but may include behaviours such as actively avoiding work, being disruptive and involving negative affect such as frustration, disinterest and discomfort.

Student engagement is shaped by a range of different factors. Internal factors (within individuals) include psychological constructs like interest and motivation (Renninger and Bachrach 2015). But student engagement does not happen in a vacuum. It is enabled, supported or constrained by the opportunities and actors within a particular context. External factors (outside individuals) include, for instance, the nature of family and peer support (Bempechat and Shernoff 2012) and the role of teachers and their approaches to teaching and interacting with students (Meece et al. 2006; Pianta et al. 2012; Roorda et al. 2011). Understanding the role played by these factors is important because student engagement is a dynamic and cyclical process. This means that positive engagement experiences are likely to shape a learner's dispositions toward further engagement. Negative engagement experiences or a lack of opportunities to engage altogether, on the other hand, are likely to have the opposite effect and deter students from engaging in the future (Lawson and Lawson 2013).

In this study, we adopted the conceptualisation of student engagement as proposed by Fredricks and her colleagues (see above), attending to the instances of participation (behavioural engagement), interest and attitudes (affective engagement) and persistence and psychological investment to learn (cognitive engagement). We considered all levels of student engagement, paying particular attention to the factors enabling and thwarting engagement. It was important to examine, for instance, whether a 'passive-looking' engagement was a product of a student's limited interest in actively taking part-or perhaps the lack of opportunities afforded by the context to enact 'deep' and 'agentic' engagement.

The student engagement literature has been critiqued for placing the responsibility for engagement predominantly on the shoulders of individual students and the out-of-school support they receive (Yazzie-Mintz and McCormick 2012). Like Fredricks and McColskey (2012) and Lawson and Lawson (2013), we argue for a greater focus on the role of specific contexts. We also note that insufficient consideration has been given to how a particular practice that supports engagement for one student might simultaneously make engagement difficult for another by affecting, as Eccles (2005) has described it, the 'person-environment fit'. Studies focusing on marginalised and disadvantaged students have been illustrative of the importance of considering such 'fit' between students and the contexts and opportunities they have to engage. As many have pointed out (e.g. Bingham and Okagaki 2012), the issues of cultural discontinuity and incongruence that some students experience in education may make 
engagement especially difficult. Thus, we argue that adopting a sociological perspective to studying student engagement (in our case, with science) can usefully complement existing work which has largely taken a psychological approach (see, for instance, the Handbook of Research on Student Engagement, edited by Christenson et al. 2012a, for an overview of conceptual and methodological concerns relating to student engagement).

The importance of considering the contexts and opportunities for engagement has also been highlighted in the science education literature. Carlone and her colleagues (Carlone et al. 2011), for instance, have argued that it is vital to consider what sort of 'normative practices' permeate a particular educational context and, thereafter, how students are expected and obligated to engage within such spaces. Whilst 'normative practices' may work well for some, those who do not meet the expectations or do not behave in ways that are valued by the school may, in turn, encounter challenges and subsequently find engaging with science in the context of science lessons difficult. We share the concerns about the opportunities and expectations that students must negotiate and thus seek to unpack the 'fit' between that which the students bring with them into the classroom and the possible ways of being that they are able to inhabit in order to engage. To understand the ways in which varied resources, dispositions and ways of being/talking/thinking are recognised, supported and valued within the science classroom, we turn to the Bourdieusian conceptual framework.

\section{Bourdieusian Conceptual Framework and Science Education}

Pierre Bourdieu's $(1977,1984,1986)$ work on the reproduction of social inequalities has been widely used in education research to examine and explain the persistence of stratified social patterns (Harker 1984; Reay 2006; Reay et al. 2010). Bourdieu argued that education plays a key role in reproducing social inequalities through privileging particular ways of talking, thinking, being and behaving that are typically held by the groups in socially advantageous positions (Bourdieu and Passeron 1990). Students from working class backgrounds, on the contrary, tend to be more likely to struggle with 'getting on' and feeling comfortable with the ways of talking and behaving that are recognised and valued in mainstream educational contexts. Whilst Bourdieu has focused on social class as the main factor in social inequalities, his work has been extended by other scholars to include ethnicity (Carter 2003; Modood 2004; Yosso 2005) and gender (McNay 1999). As scholars like Crenshaw (1991), Collins (1993) and Yuval-Davis (2006) have noted, inequalities are shaped by the intersectionality between multiple social axes.

In this study, we draw on three key concepts originally proposed by Bourdieu: 'capital' (cultural, social and economic resources), 'habitus' (internalised dispositions) and 'field' (a context with its norms and expectations). Bourdieu's theoretical ideas have previously been applied to a range of issues within science education, including young people's identification with science and their science-related aspirations (Archer et al. 2012; Wong 2012), intrinsic and extrinsic value of science education (Claussen and Osborne 2013), the dynamics of laboratory group work (Jober 2012) and participation in informal science learning environments (Dawson 2014). We suggest that applying Bourdieu's theory to students' varying engagements with science offers a valuable contribution to science education and sociology of education scholarship. Next, we outline each of the concepts and discuss in more detail the extent to which they have been adopted and applied in science education. 


\subsection{Capital}

The term capital refers to resources that an individual possesses and is able to use for beneficial outcomes in social and economic situations (Bourdieu 1977, 1986). In 'The forms of capital', Bourdieu (1986) identified three key types: economic, cultural and social capital. Economic capital includes financial resources and possessions that are directly convertible into money or material wealth. Cultural capital refers to nonfinancial assets, such as acquired knowledge (including formal education), manner of speaking and other cultural codes. Social capital includes a network of friends, family and acquaintances that provide support, such as in terms of accessing professional networks and securing more lucrative employment. Capital can increase or be built up. In science education, efforts and initiatives which seek to increase students' science knowledge, skills and experiences (e.g. Newell et al. 2015; Martin et al. 2016) can be interpreted as capital building. Equally, projects which seek to enthuse and inspire students through introducing them to people working within the discipline (e.g. Scogin and Stuessy 2015; Jurow et al. 2008; van Eijck and Roth 2009) can similarly be viewed in this way. Yet, not all capital is valued equally, for it depends on the extent to which capital is recognised as symbolically legitimate within a particular context. For example, the resources of the dominant (middle-class and, in Western contexts, White) social groups are regarded highly within mainstream institutions, such as schools (Calabrese Barton and Tan 2009; Carter 2003; Yosso 2005). The resources of others (lower-class and non-White), on the other hand, are deemed to be of less value (Delpit 1988; Nash 2002). Grenfell and James (1998) have explained the inequalities arising from different levels of dominantly valued capital that people have:

\footnotetext{
... we do not enter fields with equal amounts, or identical configurations, of capital. Some have inherited wealth, cultural distinction from up-bringing and family connections. Some individuals, therefore, already possess quantities of relevant capital ... which makes them better players than others in certain field games. Conversely, some are disadvantaged. (Grenfell and James 1998, p. 21)
}

Possessing the 'relevant' resources can therefore afford some students privilege. Having resources that are less valuable within the dominant education system might, on the other hand, afford limited advantage (see also the literature on 'community cultural wealth' by Yosso 2005, 'funds of knowledge' by Moll et al. 1992, and 'epistemological resources' by Hammer and Elby 2009, for further discussions about non-dominant resources and ways of thinking within mainstream social and cultural systems).

\subsection{Habitus}

Habitus refers to a set of deeply embedded and internalised dispositions that an individual acquires through experience, such as growing up within a particular social environment. People who have similar experiences are more likely to acquire a similar set of dispositions for evaluating and understanding the world (Bourdieu 1990b). Habitus plays an important role in shaping what someone considers to be possible and desirable for them and reflects the taken-for-granted attitudes and perceptions that seem natural for people like them. In Bourdieu's words, habitus includes

\footnotetext{
... the conditions of existence which, in imposing different definitions of the impossible, the possible, and the probable, cause one group to experience as natural or reasonable practices or aspirations which another group finds unthinkable or scandalous, and vice versa (Bourdieu 1977, p. 78).
} 
The significance of habitus lies in its role to inform and generate practices, making some foreseeable and taken-for-granted, whilst others unthinkable. For instance, habitus affects whether students find science to be for them, or not (Archer et al. 2012). Students who internalise the idea that science is not a possible or desirable trajectory tend to be less likely to aspire to doing science in the future. In addition to their upbringing and socialisation within the home context, itself shaped by socioeconomic factors and ethnic and cultural considerations, students' dispositions towards or against science are shaped, challenged or reinforced by their experiences at school and other contexts in which they spend their time (Archer et al. 2012; Bourdieu 1984; Bourdieu and Passeron 1990).

\subsection{Field}

Capital and habitus need to be understood in relation to a particular field. Field is not merely a physical setting, but it includes a set of rules, regularities and relations. Bourdieu described field as 'a network, or a configuration, of objective relations between positions' (Bourdieu and Wacquant 1992, p. 97). In an educational setting, the field encompasses the structures and mores of the classroom: the relative positions of the students and teachers; the expected ways of behaving set by the wider school and the individual teacher; and the norms for any interaction - between a teacher and students, and between students themselves. In order to succeed, students are expected to observe and play within the field's 'rules of the game', although it is important to note that these rules are not necessarily made explicit (Bourdieu 1984). In short, it is the field that determines how resources (capital) are perceived and valued in relative terms, and it is the field that governs the ways in which particular behaviours (interplay of habitus and capital, see Davey 2009) are recognised as legitimate. Students who have the 'right' capital to leverage within their lessons and whose habitus 'fits' with what is expected and valued at school are likely to feel more at ease and, consequently, do better.

Bourdieu discussed how a habitus that aligns with the field is analogous to being like a 'fish in the water':

... when habitus encounters a social world of which it is the product, it is like a "fish in the water"; it does not feel the weight of the water and it takes the world about itself for granted (Bourdieu and Wacquant 1992, p. 127).

Following this logic, students who find themselves in a social context that makes them feel like a 'fish out of water' are more likely to struggle participating in the activities and succeed. Whilst some science education scholars have considered ways in which specific contexts and practices make possible or prevent students from participating, learning and identifying with science (Carlone et al. 2014; Thompson 2014), we suggest that overall, insufficient attention has been paid to the role of the field within science education.

\section{Research Study}

\subsection{Data Collection}

The study took place during one academic year in Mr. Okello's class in Northfields School (all names are pseudonyms), an inner city secondary school in London, UK. According to the Office for Standards in Education, Children's services and Skills report, the school had a higher than 
national average proportion of students eligible for free school meals, from minority ethnic groups and those who spoke English as an 'additional' language (i.e. students for whom English is not their first language). The data were collected as part of a larger project entitled Enterprising Science, a 5-year partnership between University College London, King's College London and the Science Museum Group, which focused on young people's engagement with science.

All students in Mr. Okello's class $(n=29)$ were invited to participate in the study. An agreement was sought from their parents as well as from themselves. Consent was received from 14 students. We collected data using multiple methods: science lesson observations, discussion groups and interviews with students, and interviews with Mr. Okello. These different data enabled us to capture both observed and self-reported student engagement, triangulate our findings, as well as examine the influences that shaped how students engaged with science. The majority of data were collected during 2015-2016, when students were in Year 8 (aged 12-13). In addition, we include biographical student data collected at the end of their previous academic year (interviews and discussion groups), to add to the in-depth understanding of students' habitus and capital, and how these might contribute to their engagement with science. Over the course of our observation year, Mr. Okello participated in a professional development programme as part of the wider research project. The programme involved teachers reviewing their practices and implementing changes in their pedagogy. Such changes were enacted toward the second half of the year and were reflected in the data collected, as we elaborate further below.

To understand the field of Mr. Okello's class and the nature and levels of student engagement with science, his science lessons were observed once every 2 to 3 weeks over the course of the school year. The researchers sat at the back of the classroom and kept notes either by hand or electronically, using a laptop or a tablet. Observations followed a schedule that was developed and agreed on by the research team. We considered student engagement in broad terms, drawing on Fredricks et al.'s (2004) multidimensional model of engagement consisting of behavioural, cognitive and affective-emotional engagement, and recorded different levels of engagement, such as how active and visible, or not, student engagement with science was. The focus was thus on students' behaviour, participation, whether they were ontask/off-task and how they interacted with their peers and their teachers. At the end of each lesson, we shared our observations with Mr. Okello and kept field notes of these informal conversations. As not all students in the class consented to taking part in the research, we were not able to audio or video record the lessons. Whenever possible, however, we tried to capture students' verbatim quotations, as well as kept detailed descriptive notes on the teaching practice and class dynamic as a whole. As other scholars have noted, it is not always easy to 'see' engagement in practice, as some aspects might be more visible to the eye than others (Bempechat and Shernoff 2012; Nasir and Hand 2008). Following Nasir and Hand 2008 (p. 173), we were cautious that 'sitting and listening are not necessarily distinguishable from sitting and daydreaming'. Therefore, wherever possible, we triangulated our observation data with students' own accounts of their engagement with science.

To ascertain students' own perceptions with respect to what constitutes engagement and to gather data about their science-related resources and dispositions (along with demographic data), we conducted interviews and discussion groups. Six discussion groups were organised during or after the students' science lessons, usually in an empty classroom or a nearby office. Several students took part in a discussion group more than once. We asked students about their engagement with science during lessons, who they considered to be 'science people' in their class and why, and what kind of participation they thought was valued by their teacher. During 
the final round of discussion groups, we also asked students about specific behaviours and events that we had previously observed during their lessons. All discussion groups and interviews were audio-recorded and transcribed.

To further examine the field, its rules of the game and what was recognised and valued, we interviewed Mr. Okello at the beginning and at the end of the academic year. The aim of the initial interview was to elicit what he perceived to be 'good' student engagement with science, and discuss individual students whom he regarded to be particularly engaged or disengaged. These data provided us with a wider understanding of how students were expected to act during their science lessons and what behaviours were traditionally celebrated in Mr. Okello's class. In the second interview, we sought to establish Mr. Okello's views regarding engagement following his participation in the professional development. These data contributed to our refinement of the professional development programme and associated resources (Godec et al. 2017).

\subsection{Data Analysis}

We began our data analysis by mapping out student engagement with science. We coded for instances of visible engagement with science in our observation data (e.g. students giving explanations, asking questions, responding to the teacher's science-related questions, being ontask, claiming voice/space (Carlone et al. 2014), indicating excitement about topics discussed), as well as instances of engagement that appeared more passive or 'compliant' (e.g. writing notes, appearing to listen, quietly following instructions) and moments where students were explicitly disengaging (e.g. disrupting the lessons, showing boredom, refusing to engage with tasks). Noting that engagement cannot always be captured through observations alone, we compared observation data with students' narrated accounts. Whilst students' engagement with science was not consistent throughout our observations, we were able to organise our data according to how students engaged most of the time. Of the 14 students in the study, three were actively and visibly engaged the majority of the time, nine mostly exhibited passive or 'compliant' engagement and two were regarded as mostly being disengaged. We then coded students' science-related resources and dispositions in the data from student discussion groups and interviews (e.g. their attitudes and identification with science, participation in sciencerelated activities outside the science class, and other demographic and family data). We were particularly interested in those students who spoke about some interest and dispositions towards science, which we examined alongside how they engaged with science during their science lessons.

Next, we reviewed our field notes to examine the field of Mr. Okello's class: what opportunities there were for students to engage; what may have made engagement difficult; which forms of engagement were recognised and praised; and which went unnoticed or were reprimanded for not being the 'right' kind. We looked for patterns in the engagement data and 'interesting' engagement moments, which we explored alongside the factors we interpreted as enabling or hindering student engagement. When considering the analysis of engagement data through a Bourdieusian lens, we examined how students' habitus and capital (manifested in their behaviours, ways of talking and participating during the lessons; see Davey 2009) interacted with the field of Mr. Okello's class. Our intention was not to evaluate the quality of Mr. Okello's teaching practice and we acknowledge that teaching practices vary and may even do so within single lessons in response to moment-by-moment changes in behavioural dynamics (Carlone et al. 2014). Our aim, instead, was to look at how the particular context of 
Mr. Okello's class supported and valued some resources and behaviours (and consequently, some students) over others, and specifically, we sought to understand student engagement with science through focusing our attention on the notion of field, that is, the structures and mores of Mr. Okello's science lesson.

In the next section, we set the scene of Mr. Okello's science class and then introduce two students: Adnan and Sharifa. We spoke to both at the end of Year 7, and both stayed in the focus Year 8 class throughout the year when we observed the science lessons. We chose to present these two students in the article on the basis that they both expressed interest in and dispositions towards engaging with science, yet exhibited markedly different outward forms of engagement during the science lessons. This enabled us to compare and contrast how the field may have differentially supported them to engage with science.

\subsection{Setting the Scene}

We begin by introducing the field of Mr. Okello's science class: what happened in a regular lesson. Mr. Okello's science lessons were lively and loud. He described his approach to teaching as 'relaxed' and 'interactive'. He commented 'I hope I'm a facilitator, I facilitate'. In interacting with the students, Mr. Okello typically posed questions to the class, asking for scientific knowledge, and instructed students to raise their hands to answer. From the observation notes, it was evident that the class was largely dominated by a small group. As astutely observed by Leonore: 'only three boys put their hands up and that's it'. These students consistently volunteered to contribute and, when picked by Mr. Okello, offered (usually scientifically correct) answers to his questions. The following excerpts illustrate typical interactions in Mr. Okello's science lessons:

\footnotetext{
Mr Okello asks the class 'Why does it matter if rain water is acidic?' Adnan volunteers to answer, stretching his hand up high: 'It's corrosive!', he shouts loudly when called. Mr Okello compliments him: 'Yes, that is correct'. (Lesson observations, November 2015).

Mr Okello says that they will model two types of outbreak, first an 'innocent flu' that 'usually can't kill', then a more serious virus. Damon says out loud 'but it can kill babies and old people!'. Mr Okello: 'That's right Damon, flu can kill babies and old people, good answer'. (Lesson observations, January 2016).

Damon volunteers, then Mr Okello calls Nadia and then Ruben. But, Jafi is eager to answer too, his hand is up, he calls 'me sir!' (Lesson observations, February 2016).
}

The students' behaviour and responses described here exemplify what we saw to be an active form of engagement with science in the lessons we observed. Students usually tried to answer questions using scientific concepts and terminology, often illustrating the knowledge gained outside the class. In this way, they experimented with 'talking science' (Lemke 1990) and seemed keen to display their knowledge to the teacher and their peers (see also Archer et al. 2017). They were comfortable with claiming voice/space in the lessons (Carlone et al. 2014), which was indicated by their regular movement around the class (which few other students did) and speaking out loud without being called. Their forms of participation incurred repeated praise, individually and in front of the class. Significantly, these students were often praised for their contributions even when these were shouted out - an act which might normally be chastised for going against the explicit behaviour protocol of the school. Whilst Mr. Okello repeatedly reminded students to raise their hands and wait to be called before speaking up, it was ultimately the act of making visible contributions that counted. Further to volunteering to answer Mr. Okello's questions, these students would also show their keen and active engagement in other ways, such as asking for additional work (if they finished with a task or 
experiments earlier than their peers), calling the teacher over to ask further questions, or telling him more about their in-depth knowledge. These behaviours fit with the descriptions of agentic and strong engagement discussed in the student engagement literature (Reeve 2012; Reeve and Tseng 2011).

Behaviours involving active and confident displays of knowledge were expected of students and resulted in positive recognition. When asked during an interview to describe what engagement he expects in his class, and who he considered to be a 'good' science student, Mr. Okello responded:

\footnotetext{
Students who are always willing to give answers or always willing to answer questions ... and who seem most excited by the discussions [...] just somebody who's willing to ask me for further instructions if they do not get it. And who is not willing just to sit there and do nothing and wait for you to come round. Somebody who's always willing to engage in conversations and discussions. (Teacher interview, June 2016).
}

Active participation and being 'willing' to engage appeared to play a key role in what was expected and valued in Mr. Okello's classroom. A similar view of what constituted good student engagement was echoed by the students, who seemed to be aware of at least some of the expectations of what counted as engaging with science. Students described their most science-engaged peers in terms of 'contribution, paying attention, just being good really', 'people who work and contribute', who were 'super confident', 'clever' and showing that they do 'a lot of extra work outside school'. The students who performed in this way were recognised by both Mr. Okello and their peers as 'good' science students (i.e. engaging appropriately) and had dominant positions in the field.

On the other hand, there appeared to be little opportunity to actively participate in the lessons for those who were quieter, less confident or who did not have the 'right' resources to draw upon. For example, we observed instances when students who attempted to speak up in class experienced put-downs by their peers for not speaking 'properly'. Frequent reprimands were made for answering questions in an inadmissible manner, using incorrect terminology or with insufficient confidence. For instance, when one student pronounced a scientific term incorrectly, a classmate would interrupt her with a demand to 'Say it properly!' On another occasion, when a student tried to explain the characteristics of porous materials, another criticised him for 'not saying it right'. As we discuss further in the Sharifa's case below, the field - constructed by both the school structures, the teacher, and the students - was set up in such a way as to prevent recognition of any forms of science engagement not sanctioned by the teacher. In short, engagement with science was made difficult, undesirable or even impossible for students whose behaviours and resources did not meet the expectations of the field.

\section{Findings}

\subsection{The Role of Field in Enabling Engagement: the Case of Adnan}

The field of Mr. Okello's class enabled and supported students who were confident, proactive and who had scientific knowledge upon which to draw. To explore in more depth how the interactions between students' habitus and capital with the field of Mr. Okello's classroom influenced student engagement with science, we focus on Adnan, one of the most actively engaged students in the class. Adnan was a high-achieving science student who enjoyed and valued science. He self-identified as a 'sciencey' person, a characteristic which we interpret as 
being representative of his habitus. Habitus is formed through socialisation at home and through one's experiences growing up (Bourdieu 1984; Bourdieu and Passeron 1990). In Adnan's case, it would appear that science and learning were held in high regard by his family. Adnan came from middle class social background and his parents clearly valued science and learning: Adnan's mum worked as teacher, and Adnan described his father as previously doing 'something related to chemistry'. His parents also encouraged his love of reading science books. Adnan added that he also enjoyed learning about science from the Internet. During science lessons, Adnan consistently participated in loud and visible ways, raising his hand and offering lengthy explanations, demonstrating his scientific knowledge. When asked about who engaged most in their class and who were thought of as 'sciencey people', most students pointed at Adnan because he was the one 'who always answers a question if sir asks' (Tolek). His classmate Leonore commented that Adnan used 'fancy words' during the lessons and Christopher mentioned that Adnan appeared to 'know a lot about science'. From the teachers' perspective, Adnan was regarded to be one of the more 'sciencey' ones in their class. Mr. Okello said that Adnan was 'good science student but he's also very sciencey ... he's got a love for science'.

Focusing on Adnan's capital and habitus shines a light on why the field of classroom 'worked' for him and supported his engagement with science. The experiences and resources Adnan had available were the 'right' (dominant) kind to help him engage with science. His capital (e.g. his knowledge of science from books and family conversations) had a high exchange value in class, and Adnan was able to successfully leverage these resources. It was not only that he was able to share his scientific knowledge, he was also able to present this knowledge in a way that was valued. As Jober (2012) has argued, ways of talking might be as important as what one is talking about. It is vital to note here that Adnan's success in school science was also a feature of his 'feel for the game' (Bourdieu 1990a) and, moreover, his ability to play the game well. We suggest that Adnan was able to 'read' the expectations of the field. His active and visible engagement with science was celebrated by his teachers. This resulted in positive status attribution, which Bourdieu argued is 'the best-hidden effect of the education system' (Bourdieu 1984, p. 23), helping to reproduce and reinforce particular ways of being within a given field. As Harker (1984 p. 118) remarked, 'those with the appropriate cultural capital are reinforced with "success", while others are not'. Through his engagement with science being consistently praised, we argue that school science reinforced Adnan's scientific habitus, a feeling that of 'science is for me'.

For Adnan, his capital and habitus were aligned with the field of the science classroom in that his active, vocal contributions matched his teachers' expectations of how a 'good' science student should behave. Science discourses were 'normal' and comfortable for him, and his resources were valued and reaped positive recognition. In sum, we interpreted Adnan as exhibiting an embodied habitus (in his dispositions and ways of being) that fitted well with the celebrated ways of behaving and participating in his science classroom, and as possessing capital (e.g. scientific knowledge and terminology and behaviours) that were of the 'right' type to be appreciated in his science classroom. These emphases here are important. It is not Adnan's knowledge and attitudes per se that afforded his success, but the alignment of his knowledge and attitudes with the requirements of the classroom. Adnan was like a 'fish in the water' (Bourdieu and Wacquant 1992): he enjoyed his science lessons because he understood and was happy and comfortable to play the game according to the rules, had sufficient resources of high exchange rate to do so and, as a result, found lessons rewarding and contributing to a positive sense of self. Science lessons 'worked' for Adnan and his behaviour was seen to be one of engagement. 


\subsection{The Role of Field in Limiting Engagement: the Case of Sharifa}

Whilst the structures and systems of Mr. Okello's classroom enabled and supported engagement with science for students like Adnan, they made engagement difficult for students whose habitus and capital did not align with the field. For those who expressed disinterest in science and had low levels of dominant science capital, instances of engagement were rarely observed. In this section, we discuss how engagement with science appeared to be constrained by the field. We focus on Sharifa who at the outset of the year had some science-related resources and dispositions, but for whom the specific field of Mr. Okello's class made engagement difficult and at times even impossible. Sharifa, like Adnan, had at the end of previous academic year (Year 7) described herself as a 'sciencey person', in part due to the influences of her family: 'my mum, she likes science and I like science as well and all my brothers like science, and my cousins and then they all did like science degrees and stuff'. Despite being from a working class background as indicated by levels of parental education and employment (her mum stayed at home and her dad worked in a shop), the example of family members studying for science degrees would suggest that Sharifa's family's science capital (Archer et al. 2015) was relatively high. In Year 7, Sharifa intimated that she would like to become a scientist or a science teacher, suggesting strong dispositions towards engaging with science.

Whilst it appeared that Sharifa, like her peers, understood the importance of visible and overt displays of knowledge to be recognised as engaged by the teacher, she did not perceive such behaviours as comfortable or desirable to enact herself. Consequently, she resisted acting in such ways. Sharifa described her peers who she considered to be modelling 'good' engagement with science as giving 'an essay for every question' and using 'all these big words'. She showed disdain for their behaviours, commenting that these students were 'annoying' and 'they show off too much ... there's a limit, isn't it?' She was critical of their constant calls for the teacher's attention during science lessons: 'they do all this hand stuff and it's like they bend the whole hand over, man, it's creepy'. She was also derisive of the ways in which some students made others feel 'dumb' and 'bad about themselves'. The reasons for this disdain might lie in working class contempt for school engagement (Archer et al. 2007; Lucey et al. 2003), which was arguably exacerbated by the subject in question being the high status discipline of science. Applying a Bourdieusian lens, we see this as a disjuncture between Sharifa's habitus (dispositions she considered to be desirable and comfortable) and what she perceived the rules of the game within the field to be. Sharifa was like a 'fish out of water': despite valuing science and intimating that science might be a feature in her future, she rendered active engagement with science undesirable - the expected behaviours were not comfortable for her to enact. Sharifa, we suggest, was unwilling to play by the rules of the game of Mr. Okello's class (Bourdieu and Wacquant 1992).

From the dominant perspective of engagement consisting of giving loud, confident, 'correct' answers, Sharifa would be labelled disengaged. However, from our observations, this was not necessarily the case. During the lessons, Sharifa was mostly on-task, writing in her notebook and completing activities as instructed. Although she did not participate in highly overt ways like some of her classmates, we argue that she was engaged, as the following excerpts from the observation notes illustrate:

Sharifa, sitting at the back, is very quiet, but does the work required. (Lesson observations, November 2015).

Sharifa has filled in most of the sheet; most others do not do it. (Lesson observations, February 2016). 
Sharifa is sitting at the back by herself, making notes, has not spoken a word. (Lesson observations,

March 2016).

Sharifa admitted that she was 'just quiet in general' and her classmates agreed she was one of the 'quiet people' (Tolek). She spoke about being engaged during the lessons, just not in the visible ways. She said 'I don't really like putting my hand up', but added that she was not off-task ('I just write in my book'), as corroborated by our observation notes. Other students agreed that 'some girls just do their work, without talking' (Tolek). Applying the student engagement lens, Sharifa might be labelled as engaging 'compliantly' (Crick 2012), but this, we argue, does not seem to be a fair or accurate portrayal. Rather, we suggest that the interplay of capital, habitus and field prevented the depth of Sharifa's engagement being acknowledged appropriately; she was not valued for her quiet and diligent work.

By not engaging with science in the expected and celebrated ways, we suggest that Sharifa had less possibility to be recognised as 'scientific'. The quiet and conscientious engagement she exhibited received little recognition in Mr. Okello's class, where students were required to actively show their enthusiasm for science. Her behaviour (reflecting her habitus and capital) was not regarded as valuable in comparison to Adnan's loud and confident contributions; rather, it was given a lower status. Mr. Okello described students such as Sharifa as having 'no engagement at all in the lesson and you really have to fight hard just to get something out of them' and concluded that 'those kids, I would say are less engaged'. In class, Sharifa received neither praise nor censure and as a result was effectively disregarded by her teacher. In recognising and rewarding loud and active contributions, whilst discounting other ways of participating, teachers can be seen as key in labelling and shaping the extent of student engagement in science. In the case of Mr. Okello's class, the classroom norms reinforced a notion of 'sciencey-ness' for students like Adnan, but sent a message to Sharifa that science was not for someone like her. Over time, the field's expectations had accumulated and appeared to influence her identification and engagement with science. When we spoke to Sharifa at the end of Year 7, she confidently self-identified as a 'sciencey person' and aspired to a career in science. In Year 8, her relationship with science was no longer strong, she did not see herself as 'sciencey' (a label she ascribed to other confident and outspoken peers) and had a new aspiration of wanting to become a lawyer. Through teachers' explicit valuing and tacit celebration of some forms of engagement with science over others, it appears that students were developing strong views about who science was for and what it meant to be scientific. By narrowly framing celebrated engagement, it would seem that for some students, their science education experiences in the classroom were impoverishing their potential engagement with science (Carlone et al. 2014; Gonsalves et al. 2013).

\subsection{Potential for Broadening the Field}

Our observations later in the year coincided with My Okello's involvement in the professional development programme and his implementation of a new teaching approach (Archer et al. 2018; Godec et al. 2017). Thus, we increasingly saw Mr. Okello trying to open up his teaching to create more engagement opportunities for more students. In most cases, these opportunities (i.e. for more students to have something to contribute, and feel they were supported and acknowledged by the teacher and other students) occurred when students' various resources were welcomed and valued, and when effort was made to support participation from students 
who were otherwise ostracised by their loud and confident peers, or who felt less confident participating. Mr. Okello, in addition, attempted to elicit not only narrow curriculum knowledge, but also broader experiences that related to the topics in question, such as knowledge about family members' jobs, a medical diagnosis students had a personal experience with, or hobbies that related to the science topic under discussion. At the end of the year, Mr. Okello discussed his attempts to 'broaden the field' in the follow way:

I have found with [the teaching approach], I am taking the context and I am applying it to the experience of the individual students. I think that makes it far more relevant and it's easier for them to engage with. I start off with a topic and I have to find something that they all know, which may be related to it. But not in an obvious way. So, if we are learning about soundwaves, I talk about music, ask who plays an instrument, sings or beatboxes. I get them sharing their expertise first. (Teacher interview, June 2016).

In broadening the field, Mr. Okello was able to support students whom he had previously regarded as quiet or disengaged to claim voice in the classroom (Carlone et al. 2014). For example, during a lesson on soundwaves, Mr. Okello asked the class about their own experience of sound and vibrations. Christopher - a normally quiet boy whom we had consistently observed being on task but rarely contributing to classroom discussionsresponded with a contribution about his grandmother. Our field notes from the ensuing interaction are as follows:

Christopher (sitting close to Mr Okello) tells Mr Okello something about his grandmother feeling the vibrations. Mr Okello: 'Everyone, Christopher has something really interesting to say here, you should really listen!' The class calms down and listens. Christopher says that his grandmother, who lives with them, is deaf, and she told him that deaf people develop other senses more, so she can feel the vibrations. Mr Okello repeats some of what Christopher said (Christopher is softly spoken and in comparison to other loud students his voice does not reach as far), mentions grandmother and vibration, 'she can't hear but she feels the vibration', 'she feels the sound'. (Lesson observations, February 2016).

This example was significant because it enabled Christopher to gain legitimacy in the science classroom by sharing an experience from his personal life. His knowledge and experience from outside school had been recognised in the classroom, which in turn contributed to Christopher being considered engaged. This occasion also stood out for Christopher, who mentioned the instance during the discussion group. Sharifa (discussed above) similarly recognised a change the field of classroom which led to her personal experience being acknowledged and validated. In her discussion group, Sharifa recalled the following:

Sharifa: He [Mr Okello] asked all the people that have asthma, put your hands up or something if you have asthma.

I: Yeah, did you get to share your experience of that?

Sharifa: Yeah, some of us.

I: Do you remember how that went?

Sharifa: He just asked us, like... What type of asthma do you have? Do you have to get flu jabs and stuff and you have to get flu jabs, like, every other month or something. Every year. (Discussion group, March 2016).

By eliciting students own experiences, Mr. Okello was able to reduce the 'gap' between the field of the science class and the students' own capital and habitus. Students' knowledge and experience from outside school, such as about a grandparent feeling vibrations or a personal experience of living with asthma, gained a higher exchange value in the class (Rios-Aguilar et al. 2011; Skeggs 2004). In this way, Mr. Okello was able to improve the alignment between students' habitus and capital, and the field of science class - and create opportunities for students to engage with science. 


\section{Discussion}

In this article, we have discussed our analysis of student engagement with science through a Bourdieusian lens, arguing that attending to the field can help explain the variance in student engagement. We have considered a science class to be a field (nested within a larger field of an education system) and student engagement a form of practice produced at the interface of habitus, capital and field. We argue that student engagement with science needs to be regarded in relation to the opportunities students have, how they are expected to engage, who can do so and who can not. This, we suggest, depends on the alignment of their capital and habitus with the field. Our argument echoes those of Carlone and her colleagues, who noted that:

School science is subject to strong institutional and cultural narratives of what counts as legitimate science, is often configured too narrowly, and leaves little room to celebrate and productively leverage different kinds of students' science-related interests and identity work. (Carlone et al. 2014, p. 863).

The field of Mr. Okello's class at the beginning of the school year enabled, supported and celebrated engagement with science for a small group of confident and outspoken students. It was mostly the students with high exchange value capital and habitus that aligned with the field who were able to contribute to class discussions. On the contrary, students with less dominant capital (and by extension, less confidence to claim voice in the science lessons) were deterred from trying to engage with science in the active ways that were celebrated - or considered it impossible to engage in such manner altogether. In structuring the field narrowly and creating limited definitions of what it meant to be engaged, students whose habitus and capital did not fit risked being disadvantaged. The tacit approval granted by the teacher for loud and active contributions meant that the field offered few engagement opportunities to students who felt they were not able to speak up in a loud, confident and dominant manner. When students' behaviours were at odds with what was expected or 'normalised' within the classroom, and these behaviours were reprimanded or rejected, a powerful message was sent to all students about who science is for, who can engage and who cannot.

The field was produced and maintained by the teacher as well as by the students. Students played an important role in policing the field, closing down opportunities for their peers' engagement, both directly through shutting down 'incorrect' ways of participating and through their claims to voice and space at the expense of engagement opportunities for their quieter and less confident peers. The comments that science should be spoken 'properly' influenced students' perceptions about who was allowed to speak in the classroom and in what ways (Archer et al. in press; Lemke 1990). We suggest that speaking up in class was intimidating for students who were less confident in their knowledge and who, consequently, feared being reprimanded. Bourdieu argued that when certain ways of being and doing are regarded and labelled as inappropriate, this might lead to an individual's withdrawal from the field (Bourdieu 1974; Nash 1990). In the case of Mr. Okello's class, the act of hindering students' participation resulted in their reluctance and anxiety about speaking up.

When students engaged in ways that did not meet the field's expectations, their engagement was deemed less valuable or went unrecognised. Despite articulating dispositions towards science, some students found it difficult to engage with science during their lessons, particularly in the active and visible ways that both students and teachers considered to be particularly valuable. This lack of recognition arguably influenced their future engagement and dispositions related to science. Sharifa, for instance, explicitly rejected the 'show off' behaviours exhibited by her top set peers and her quiet, less visible engagement went underrecognised. 
Over time, she had ceased to identify as being 'sciencey'. We argue that by not recognising alternative forms of engagement as legitimate, teachers may curtail students' self-belief in science. What is recognised, or not recognised, is shaped by the field of the science classroom and its 'habitus-forming force' (Bourdieu 1967). Based on our data, we cannot determine whether her move away from science was shaped by her classroom experience alone. Whilst changing a direction is not problematic in itself, the issue arguably becomes problematic when a student closes the door to science because he or she feels out of place, and not belonging in science. A focus on the field calls for greater attention to broaden structures and practices, and advocates for deeper reflection from those who manage such structures. The effort should be to make engagement possible for more children, keeping more doors open as they move towards the future.

Scholars have previously argued that students' resourcefulness and ability to decode the demands and expectations of a particular context is pivotal in helping them navigate oppressive structures and is critical for minoritised students to succeed within the dominant education system (Johnson et al. 2011). The argument is that if students know what is expected of them to succeed, they would be able to do what is required. Our findings, in contrast, suggest that students might well be able to read the expectations of the field (i.e. they are aware of how they should behave and participate in order to be considered a science engaged student), but this does not necessarily manifest into performances that meet such expectations. We suggest that this might be because their habitus is in conflict with the field; the expected behaviours do not align with how students feel comfortable performing. This finding further highlights the powerful role that social structures play in constraining the possibilities for student agency. Despite being able to 'read' the norms within a particular field, students might opt not to engage with science in ways they know would be required.

As we illustrated with the selected examples from Mr. Okello's classroom, an act of broadening the field can support wider student engagement, offering an effective way for educators to support diverse learners in more equitable ways. Rather than valuing predominantly canonical/curriculum science knowledge, teachers can broaden the field to recognise and value individuals' wider 'funds of knowledge' (Moll et al. 1992), such as those related to their everyday experiences. Whilst these might conventionally not be recognised as legitimate in school science (Calabrese Barton and Tan 2009), their inclusion can provide a powerful way to enable more students to become active participants in the classroom. As we have discussed elsewhere (Archer et al. 2018; Godec et al. 2017), a pedagogical approach that centres on the field and supports an ongoing reflection about practice has shown promising results in terms of helping more students connect and engage with science. Empirical data from this study suggest that an emphasis on the field is useful for understanding engagement, whatever the implicit rules, values and norms might be. Much of student engagement literature has focused on researching strategies that are likely to raise engagement most successfully in general terms, for learners overall (Christenson et al. 2012a). Less attention, however, has been paid to how opportunities that work for some students might hinder engagement for others. We have discussed the instances where the field appeared to open up and value students' resources and dispositions. Indeed, Sharifa was aware of such changes and acknowledged their impact. It is significant to note that whilst more students were valued, this did not adversely affect their other previously privileged students. However, the findings from previous research suggest that some caution might be necessary, as opening the field may lead to unfavourable responses from those who successfully navigate science learning in more traditional, narrower ways. For instance, research has found that in some cases, broadening ways of being and doing science 
resulted in negative implications for students who had been privileged within the more traditional science education spaces, but who no longer maintained this privilege when more ways became valued (Carlone 2004; Godec 2017).

The field approach to examining student engagement with science enables a focus on student diversity, an aspect that is often missing from the student engagement research agenda (Christenson et al. 2012b). In this way, our approach complements other theoretical lenses commonly used in trying to understand the timeless subject of student engagement with science, by attending to how a context supports or hinders engagement, and different levels of 'fit' or alignment it enables for what students bring with them. We further argue that a Bourdieusian theoretical lens allows us to look at why things are intractable. Bourdieu had a deterministic view of the world, seeing little potential for a shift in power and for a disruption of existing relations. We suggest that whilst individual teachers operate within a wider educational field that centres on performativity and behaviour standards, which might limit their ability to change the overall practice, they can nevertheless change the field within their own classrooms (Archer et al. 2018). The field is not static, but flexible and capable of change. Indeed, Mr. Okello's practice towards the end of the year suggests that change is readily possible. By broadening what behaviours and experiences are regarded as legitimate and valuable within the classroom, teachers can enable more students to engage with science. When many programmes continue to focus on changing students' resources and dispositions (e.g. improving their science-related attitudes, trying to excite and interest them in science), we propose that it could be useful to consider the ways in which the field can be broadened to value more highly the resources and dispositions already existing.

\section{Conclusion}

This article contributes to the science education literature by adopting a sociological perspective to understanding student engagement with science, examining how the field influences student engagement with science and what makes engagement difficult and undesirable for some. In this study, the field operated in two main ways: by enabling opportunities for engagement with science for some students but not all, and by recognising and valuing some ways of engaging with science whilst disregarding others. Being able to engage with science in celebrated ways was not only a matter of knowing and understanding the rules of the game (what is expected, recognised and valued), but also feeling comfortable to act in particular ways. Opportunities for engagement were afforded by the alignment between habitus, capital and field. When a student's capital and habitus were aligned with the field, engagement was easily recognised, valued and, consequently, reinforced. When, on the other hand, the alignment was less clear, engagement was more difficult to enact. The focus on the field provides a useful framework to help unpack the structural norms that define what and who counts as legitimately engaged in science. Moreover, it draws attention to the ways in which students' dispositions and capital become resources or disadvantages for engagement with science and thus highlights the often narrow opportunities that some students have to utilise their varied cultural backgrounds (Brickhouse et al. 2000; Calabrese Barton and Tan 2010; Carlone et al. 2014; Lemke 1990). Focusing attention on the field, as Mr. Okello increasingly sought to do, offers a fruitful course for future efforts aimed at supporting science engagement and making science education more equitable. 
Funding Information This study was part of the Enterprising Science project, a 5-year research and development project conducted in partnership with Universtiy College London, King's College London and the Science Museum Group, funded by BP.

\section{Compliance with ethical standards}

Conflict of interest The authors declare that they have no conflict of interest.

Open Access This article is distributed under the terms of the Creative Commons Attribution 4.0 International License (http://creativecommons.org/licenses/by/4.0/), which permits unrestricted use, distribution, and reproduction in any medium, provided you give appropriate credit to the original author(s) and the source, provide a link to the Creative Commons license, and indicate if changes were made.

\section{References}

Ainley, M., \& Ainley, J. (2011). Student engagement with science in early adolescence: the contribution of enjoyment to students' continuing interest in learning about science. Contemporary Educational Psychology, 36(1), 4-12.

Appleton, J. J., Christenson, S. L., Kim, D. H., \& Reschly, A. L. (2006). Measuring cognitive and psychological engagement: validation of the student engagement instrument. Journal of School Psychology, 44(5), 427445.

Archer, L., Hollingworth, S., \& Halsall, A. (2007). University's not for me-I'm a Nike person': urban, workingclass young people's negotiations of style, identity and educational engagement. Sociology, 41(2), 219-237.

Archer, L., DeWitt, J., Osborne, J., Dillon, J., Willis, B., \& Wong, B. (2012). Science aspirations, capital, and family habitus: how families shape children's engagement and identification with science. American Educational Research Journal, 49(5), 881-908.

Archer, L., Dawson, E., DeWitt, J., Seakins, A., \& Wong, B. (2015). Science capital: a conceptual, methodological, and empirical argument for extending bourdieusian notions of capital beyond the arts. Journal of Research in Science Teaching, 52(7), 922-948.

Archer, L., Dawson, E., DeWitt, J., Godec, S., King, H., Mau, A., Nomikou, E., \& Seakins, A. (2017). Killing curiosity? An analysis of celebrated identity performances among teachers and students in nine London secondary science classrooms. Science Education, 101(5), 741-764.

Archer, L., Dawson, E., DeWitt, J., Godec, S., King, H., Mau, A., ... Seakins, A. (2018). Using Bourdieu in practice? Urban secondary teachers' and students' experiences of a Bourdieusian-inspired pedagogical approach. British Journal of Sociology of Education, 39(3), 283-298.

Archer, L., Nomikou, E., Mau, A., King, H., Godec, S., DeWitt, J., \& Dawson, E. (in press). Can the subaltern 'speak' science? An intersectional analysis of performances of 'talking science through muscular intellect' by 'subaltern' students in UK urban secondary science classrooms. Cultural Studies of Science Education.

Atkinson, R., \& Mason, C. (2014). Experiments in engagement: Review of literature around engagement with young people from disadvantaged backgrounds. London: Wellcome Trust.

Atkinson, R., Siddall, K., \& Mason, C. (2014). Experiments in engagement: engaging with young people from disadvantaged backgrounds. London: Wellcome Trust.

Barriault, C., \& Pearson, D. (2010). Assessing exhibits for learning in science centers: a practical tool. Visitor Studies, 13(1), 90-106.

Bempechat, J., \& Shernoff, D. J. (2012). Parental influences on achievement, motivation and student engagement. In S. C. Reschly \& C. A. Wylie (Eds.), Handbook of research on student engagement (pp. 315-342). New York: Springer.

Bingham, G. E., \& Okagaki, L. (2012). Ethnicity and student engagement. In S. L. Christenson, A. L. Reschly, \& C. Wylie (Eds.), Handbook of research on student engagement (pp. 65-95). New York: Springer.

Bourdieu, P. (1967). Systems of education and systems of thought. International Social Science Journal, 19(3), 338-358.

Bourdieu, P. (1974). The school as a conservative force: scholastic and cultural inequalities. In L. Eggleston (Ed.), Contemporary research in the sociology of education. London: Methuen.

Bourdieu, P. (1977). Outline of a theory of practice (Vol. 16). Cambridge: Cambridge University Press.

Bourdieu, P. (1984). Distinction (R. Nice, Trans.). Cambridge: Harvard University Press. 
Bourdieu, P. (1986). The forms of capital. In J. Richardson (Ed.), Handbook of theory and research for the sociology of education (pp. 241-258). New York: Greenwood.

Bourdieu, P. (1990a). In other words: essays towards a reflexive sociology. Cambridge: Polity Press.

Bourdieu, P. (1990b). The logic of practice. Stanford: Stanford University Press.

Bourdieu, P., \& Passeron, J.-C. (1990). Reproduction in education, society and culture (Vol. 4). London: Sage.

Bourdieu, P., \& Wacquant, L. (1992). An invitation to reflexive sociology. Chicago: University of Chicago Press.

Brickhouse, N. W., Lowery, P., \& Schultz, K. (2000). What kind of a girl does science? The construction of school science identities. Journal of Research in Science Teaching, 37(5), 441-458.

Brown, B. A. (2006). It isn't no slang that can be said about this stuff: language, identity, and appropriating science discourse. Journal of Research in Science Teaching, 43(1), 96-126.

Calabrese Barton, A., \& Tan, E. (2009). Funds of knowledge and discourses and hybrid space. Journal of Research in Science Teaching, 46(1), 50-73.

Calabrese Barton, A., \& Tan, E. (2010). 'We be burnin’! Agency, identity, and science learning. The Journal of the Learning Sciences, 19(2), 187-229.

Carlone, H. B. (2004). The cultural production of science in reform-based physics: girls' access, participation, and resistance. Journal of Research in Science Teaching, 41(4), 392-414.

Carlone, H. B., Haun-Frank, J., \& Webb, A. (2011). Assessing equity beyond knowledge - and skills-based outcomes: a comparative ethnography of two fourth-grade reform-based science classrooms. Journal of Research in Science Teaching, 48(5), 459-485.

Carlone, H. B., Scott, C. M., \& Lowder, C. (2014). Becoming (less) scientific: a longitudinal study of students' identity work from elementary to middle school science. Journal of Research in Science Teaching, 51(7), 836-869.

Carter, P. L. (2003). 'Black' cultural capital, status positioning, and schooling conflicts for low-income African American youth. Social Problems, 50(1), 136-155.

Christenson, S. L., Reschly, A. L., \& Wylie, C. (2012a). Handbook of research on student engagement. New York: Springer.

Christenson, S. L., Reschly, A. L., \& Wylie, C. (2012b). Epilogue. In S. L. Christenson, A. L. Reschly, \& C. Wylie (Eds.), Handbook of research on student engagement (pp. 813-818). New York: Springer.

Claussen, S., \& Osborne, J. (2013). Bourdieu's notion of cultural capital and its implications for the science curriculum. Science Education, 97(1), 58-79.

Collins, P. H. (1993). Toward a new vision: race, class and gender as categories of analysis and connection. Race, Sex \& Class, 1(1), 25-45.

Crenshaw, K. (1991). Mapping the margins: intersectionality, identity politics, and violence against women of color. Stanford Law Review, 43(6), 1241-1299.

Crick, R. D. (2012). Deep engagement as a complex system: identity, learning power and authentic enquiry. In S. C. Reschly \& C. A. Wylie (Eds.), Handbook of research on student engagement (pp. 675-694). New York: Springer.

Davey, G. (2009). Using Bourdieu's concept of habitus to explore narratives of transition. European Educational Research Journal, 8(2), 276-284.

Dawson, E. (2014). 'Not designed for us': how science museums and science centers socially exclude lowincome, minority ethnic groups. Science Education, 98(6), 981-1008.

Delpit, L. (1988). The silenced dialogue: power and pedagogy in educating other people's children. Harvard Educational Review, 58(3), 280-299.

Eccles, J. S. (2005). Schools, academic motivation, and stage environment fit. In R. Lerner \& L. Steinberg (Eds.), Handbook of adolescent psychology (2nd ed., pp. 125-153). Hoboken: Wiley.

Fredricks, J. A., \& McColskey, W. (2012). The measurement of student engagement: a comperative analysis of various methods and student self-report instruments. In S. L. Chistenson, A. L. Reschly, \& C. Wylie (Eds.), Handbook of research on student engagement. New York: Springer.

Fredricks, J. A., Blumenfeld, P. C., \& Paris, A. H. (2004). School engagement: potential of the concept, state of the evidence. Review of Educational Research, 74(1), 59-109.

Friedman, A. J., \& Ginsburg, A. (2013). Monitoring what matters about context and instruction in science education: A NAEP data analysis report. https://pdfs.semanticscholar.org/296b/3b09f6113ce3913e16e309 fe5d86031b0b92.pdf. Accessed 12 Dec 2017.

Godec, S. (2017). Urban girls' engagement with science within lessons, class visits and family visits to science museums: Interactions of gender, social class and ethnicity. (Doctoral dissertation), London: King's College London.

Godec, S., King, H., \& Archer, L. (2017). The science capital teaching approach. London: University College London.

Gonsalves, A., Rahm, J., \& Carvalho, A. (2013). We could think of things that could be science: girls' re-figuring of science in an out-of-school-time club. Journal of Research in Science Teaching, 50(9), 1068-1097. 
Grenfell, M., \& James, D. (1998). Theory, practice and pedagogic research. In M. Grenfell \& D. James (Eds.), Bourdieu and education: Acts of practical theory. London: Falmer Press.

Hammer, D., \& Elby, A. (2009). Tapping epistemological resources for learning physics. The Journal of the Learning Sciences, 12(1), 53-90.

Hampden-Thompson, G., \& Bennett, J. (2013). Science teaching and learning activities and students' engagement in science. International Journal of Science Education, 35(8), 1325-1343.

Harker, R. K. (1984). On reproduction, habitus and education. British Journal of Sociology of Education, 5(2), $117-127$.

Jober, A. (2012). Social class in science class. (Doctoral dissertation), Malmö: Malmö University.

Johnson, A., Brown, J., Carlone, H. B., \& Cuevas, A. K. (2011). Authoring identity amidst the treacherous terrain of science: a multiracial feminist examination of the journeys of three women of color in science. Journal of Research in Science Teaching, 48(4), 339-366.

Jurow, A. S., Hall, R., \& Ma, J. Y. (2008). Expanding the disciplinary expertise of a middle school mathematics classroom: re-contextualizing student models in conversations with visiting specialists. The Journal of the Learning Sciences, 17(3), 338-380.

Lawson, M. A., \& Lawson, H. A. (2013). New conceptual frameworks for student engagement research, policy, and practice. Review of Educational Research, 83(3), 432-479.

Lemke, J. L. (1990). Talking science: language, learning, and values. Norwood: Ablex.

Lucey, H., Melody, J., \& Walkerdine, V. (2003). Uneasy hybrids: psychosocial aspects of becoming educationally successful for working-class young women. Gender and Education, 15(3), 285-299.

Maltese, A. V., \& Tai, R. H. (2010). Eyeballs in the fridge: sources of early interest in science. International Journal of Science Education, 32(5), 669-685.

Martin, A. J., Durksen, T. L., Williamson, D. K., Kiss, J., \& Ginns, P. (2016). The role of museum-based science education program in promoting content knowledge and science motivation. Journal of Research in Science Teaching, 53(9), 1364-1384.

McNay, L. (1999). Gender, habitus and the field: Pierre bourdieu and the limits of reflexivity. Theory, Culture and Society, 16(1), 95-117.

Meece, J. L., Glienke, B. B., \& Burg, S. (2006). Gender and motivation. Journal of School Psychology, 44(5), 351-373.

Modood, T. (2004). Capitals, ethnic identity and educational qualifications. Cultural Trends, 13(2), 87-105.

Moll, L. C., Amanti, C., Neff, D., \& Gonzalez, N. (1992). Funds of knowledge for teaching: using a qualitative approach to connect homes and classrooms. Theory Into Practice, 31(2), 132-141.

Nash, R. (1990). Bourdieu on education and social and cultural reproduction. British Journal of Sociology of Education, 11(4), 431-447.

Nash, R. (2002). The educated habitus, progress at school, and real knowledge. Interchange, 33(1), $27-48$.

Nasir, N. I. S., \& Hand, V. (2008). From the court to the classroom: opportunities for engagement, learning, and identity in basketball and classroom mathematics. The Journal of the Learning Sciences, 17(2), 143-179.

Newell, A. D., Tharp, B. Z., Vogt, G. L., Moreno, N. P., \& Zientek, L. R. (2015). Students' attitudes toward science as predictors of gains on student content knowledge: benefits of an after-school program. School Science and Mathematics, 115(5), 216-225.

Osborne, J., \& Dillon, J. (2008). Science education in Europe: critical reflections. London: The Nuffield Foundation.

Pekrun, R., \& Linnenbrink-Garcia, L. (2012). Academic emotions and student engagement. In S. L. Christenson, A. L. Reschly, \& C. Wylie (Eds.), Handbook of research on student engagement (pp. 259-282). New York: Springer.

Pianta, R. C., Hamre, B. K., \& Allen, J. P. (2012). Teacher-student relationships and engagement: conceptualizing, measuring and improving the capacity of classroom interventions. In A. L. Reschly \& C. A. Wylie (Eds.), Handbook of research on student engagement (pp. 315-342). New York: Springer.

Reay, D. (2006). The zombie stalking English schools: social class and educational inequality. British Journal of Educational Studies, 54(3), 288-307.

Reay, D., Crozier, G., \& Clayton, J. (2010). Fitting in' or 'standing out': working-class students in UK higher education. British Educational Research Journal, 36(1), 107-124.

Reeve, J. (2012). A self-determination theory perspective on student engagement. In S. L. Christenson, S. C. Reschly, \& C. A. Wylie (Eds.), Handbook of research on student engagement (pp. 149-172). New York: Springer.

Reeve, J., \& Tseng, C.-M. (2011). Agency as a fourth aspect of students' engagement during learning activities. Contemporary Educational Psychology, 36(4), 257-267.

Renninger, K. A., \& Bachrach, J. E. (2015). Studying triggers for interest and engagement using observational methods. Educational Psychologist, 50(1), 58-69. 
Rios-Aguilar, C., Kiyama, J. M., Gravitt, M., \& Moll, L. C. (2011). Funds of knowledge for the poor and forms of capital for the rich? A capital approach to examining funds of knowledge. Theory and Research in Education, 9(2), 163-184.

Roorda, D. L., Koomen, H. M. Y., Split, J. L., \& Oort, F. J. (2011). The influence of affective teacher-student relationships on students' school engagement and achievement: a meta-analytic spproach. Review of Educational Research, 81(4), 493-529.

Scogin, S. C., \& Stuessy, C. L. (2015). Encouraging greater student inquiry engagement in science through motivational support by online scientist-mentors. Science Education, 99(2), 312-349.

Skeggs, B. (2004). Exchange, value and affect: Bourdieu and 'the self'. The Sociological Review, 52(S2), 75-95.

Skinner, E. A., Furrer, C., Marchand, G., \& Kindermann, T. (2008). Engagement and disaffection in the classroom: part of a larger motivational dynamic? Journal of Educational Psychology, 100(4), 765-781.

Skinner, E. A., Kindermann, T. A., \& Furrer, C. J. (2009). A motivational perspective on engagement and disaffection: conceptualization and assessment of children's behavioral and emotional participation in academic activities in the classroom. Educational and Psychological Measurement, 69(3), 493-525.

Thompson, J. (2014). Engaging girls' sociohistorical identities in science. The Journal of the Learning Sciences, 23(3), 1-55.

van Eijck, M., \& Roth, W.-M. (2009). Authentic science experiences as a vehicle to change students' orientations toward science and scientific career choices: learning from the path followed by Brad. Cultural Studies of Science Education, 4(3), 611-638.

Wang, M.-T., Fredricks, J. A., Ye, F., Hofkens, T. L., \& Linn, J. S. (2016). The math and science engagement scales: scale development, validation, and psychometric properties. Learning and Instruction, 43, 16-26.

Wong, B. (2012). Identifying with science: a case study of two 13-year-old 'high achieving working class' British Asian girls. International Journal of Science Education, 34(1), 43-65.

Yazzie-Mintz, E., \& McCormick, K. (2012). Finding the humanity in the data: understanding, measuring and strengthening student engagement. In S. L. Chistenson, A. L. Reschly, \& C. A. Wylie (Eds.), Handbook of research on student engagement (pp. 743-762). New York: Springer.

Yosso, T. J. (2005). Whose culture has capital? A critical race theory discussion of community cultural wealth. Race Ethnicity and Education, 8(1), 69-91.

Yuval-Davis, N. (2006). Intersectionality and feminist politics. European Journal of Women's Studies, 13(3), 193-209. 